\title{
大型ウェイングライシメータによる 林木蒸散量計測の試み \\ MEASUREMENT OF TREE TRANSPIRATION USING LARGE WEIGHING LYSIMETERS
}

\author{
吉田弘 1 ・端野道夫 2 \\ Hiromu YOSHIDA and Michio HASHINO \\ 1正会員 博(工) 徳島大学助教授 工学部建設工学科（勇770 徳島市南常三島町2-1） \\ 2正会員 工博 徳島大学教授 工学部建設工学科 (厂770 徳島市南常三島町2-1)
}

\begin{abstract}
The difference of transpiration process between coniferous and broad-leaved trees is one of the most interesting topics in forest hydrology and other study fields. Direct measurement of transpiration is indispensable for detailed discussion on the topics. The lysimeter is the most effective way to directly measure tree transpiration. In this study, large weighing lysimeters were constructed. Zelkova serrata (Japanese zelkova) and cryptomeria japonica (Japanese cedar) were planted in containers of the lisimeters, and transpiration was measured. The relationship between transpiration and heat pulse velocity which is an reliable index of transpiration rate and actual transpiration rate was investigated. Apparent differences of transpiration rate and process could not be found between two species as far as the results of the measurements.
\end{abstract}

Key Words : transpiration, weighing lysimeter, coniferous tree, broad-leaved tree, heat pulse velocity.

\section{1.はじめに}

流域での水資源開発・維持計画の策定において， 流域水収支を把握するために蒸発散量の的確な推定 が不可欠である. 本来的に流域での森林状態と雨水 流出過程との関係の把握無くして効率的な計画の策 定は困難であるが, 特に昨今のように, 流域での森 林保全も考慮に入れた総合的な計画立案が求められ る趨勢にあっては, もはや無視しては通れない問題 となっている. しかしながら, 遮断蒸発過程と蒸散 過程とが全く異なった時間と場所で生起する水文素 過程であり影響の及び方が異なるという大変厄介な 問題を克服しない限り, 従来のような両者を一括し た手法により推定せざるを得ない.

とりわけ蒸散量は現地において成木での実測が不 可能な水文量であり, 蒸散過程は, 根系による吸水, 樹液としての樹幹内の上昇および気孔からの放散と いう植物生理学的過程の影響下で生起している点で 的確な定量化を困難ならしめている.こうした問題 に対して, 著者らはなるべく現地で容易に入手しう る気象デー夕亡樹液流速の指標となるヒートパルス 速度とを利用して蒸散量を推定しうる数理モデル (ヒートパルス蒸散モデル) の提案 ${ }^{1}$ )を行い, 主と
して針葉樹（スギ）の人工林を対象に実蒸散量の推 定手法の確立に努めてきた。しかしながら，モデリ ングの良否を判断するためには，やはり成木に近い 樹木での蒸散量の実測值が必要である.ささらには現 在大きな関心が寄せられている針葉樹と広葉樹にお ける蒸散過程の定量的な比較検討までをも視野に入 れれば, 再度基本に戻って, それぞれの蒸散過程を 詳細に実測し, 両者の特性の違いを同一の方法論に よって比較検討する必要がある.ただし，樹高が20 メートルにも及ぶ成木の蒸散量を, 針葉樹と広葉樹 とについて同時並行して計測することなど前述のよ うに不可能であり, 自ずと計測対象となる樹木の樹 高や諸条件に制約と限界がある.

そこで, 樹高や樹齢の点でいくらか譲歩し, 樹高 がおよそ $5.0 \mathrm{~m}$, 樹齢が 10 年生程度の樹木を計測対象 としてライシメータにより樹木蒸散量の計測を試み た. 比較的大型のライシメー夕による蒸発散量計測 の報告例としては, 筑波大学水理実験センターに設 置されているウェイングライシメータ2) が著名であ る. 同センターの容器は直径 $2 \mathrm{~m}$, 深さ $2 \mathrm{~m}$ の円筒であ り, 重量変動を容器の変位としての光センサーに よって検出するシステムになっている. しかしなが ら，計測限界が1500kgまでであり，これまでは芝の 
ような草本を主体として蒸発散量の計測が続けられ ている.

本研究では, 容器のサイズが $1.5 \mathrm{~m} \times 1.5 \mathrm{~m} \times 1.0 \mathrm{~m}$ お よび2. $0 \mathrm{~m} \times 2.0 \mathrm{~m} \times 1.0 \mathrm{~m}$ という本邦でも他に例の希な 2 基の大型ライシメー夕を徳島県森林総合技術セン 夕一の協力を得て, 同センター構内に隣接して作成 した。 それぞれのライシメータで広葉樹（ケヤキ） と針葉樹（スギ）を植樹し，これらの蒸散量計測を 同時並行して実施した結果について報告する.

\section{2. 計測施設と方法の概要}

\section{(1) 実験設備}

2 基の大型ライシメータは徳島県森林総合技術セ ンター（徳島市庄町5-69）の協力で, 同センタ一構 内に隣接して設置された. 2 基の諸元を図-1, 図-2 と図-3に示す. $1.5 \mathrm{~m} \times 1.5 \mathrm{~m} \times 1.0 \mathrm{~m}$ の容器を有するラ イシメー夕A（図 1\&図 2) には, 植樹後約半年の 樹高約 $4.0 \mathrm{~m}$, 樹齢約 10 年のケヤキが植樹されており, 容器, 植栽土および樹木の総重量は概ね2.7トンで ある. 容器は定格 3.0 トンのロードセル（大和製衡 社製, CR2-3T-U) 3 台で支持されており, 容器, 植 栽土および樹木の総重量データは, アンプ（ユニパ ルス社製，F800-0P2）と A / D 変換ボード（ I O デー夕社製，PI0-9032C）を介してパーソナルコン ピュータ (NEC PC9801FX/U2) へ 1 分間隔で収録さ れる. $2.0 \mathrm{~m} \times 2.0 \mathrm{~m} \times 1.0 \mathrm{~m}$ の容器の容器を有するライ シメータ B (図-3）には, 樹高約 $5.0 \mathrm{~m}$, 樹齢約 10 年 生のスギが植樹されており, 植樹より約 3 年が経過 している. 容器, 植栽土および樹木の総重量は概ね 6.7トンであり, 定格3.0トンのロードセル（ミネベ ア社製，C3P1-3T-U）4台で支持されている. 容器, 植栽土および樹木の総重量データは，ケヤキの場合 亡同様にして, パーソナルコンピュータへ 1 分間隔 で収録される．公称の計測感度はライシメータ A

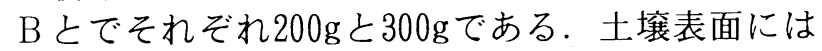
シートを掛けて土袞表面からの蒸発を防止している.

容器の底面には樹木の根腐れを防止するため排水 口が設けてあり, ここからの浸透排水量を計測して おく必要がある。 そこで, 各ライシメー夕容器の下 部の作業ピット空間内に, $0.5 \mathrm{~mm}$ 転倒（1転倒が約 15. 7cc）の転倒マス式雨量計（横河ウェザック社製, B-011-10）を設置し，排水浸透量を15.7cc每にカウ ントし, メモリーパック（東洋電子工業社製, JWA90R）に収録した。

樹液流速の指標となるヒートパルス速度のデー夕 は, ケヤキおよびスギの両方ともに, 蒸散流速計 （林電工社製，HP2）により30分間隔で計測され, メモリ一カードへ収録された後にカードリーダを介 してパーソナルコンピュータへ転送して解析に供し た。ケヤキ，スギともにごく標準的なヒートパルス 速度を示す温帯樹木であることから，ヒー夕および サーミスタの間隔は, $10 \mathrm{~mm}$ と $7 \mathrm{~mm}$ を採用し, 直径 2. $0 \mathrm{~mm}$ ，深さ $10 \mathrm{~mm}$ の小孔を胸高付近に開けて，3 本

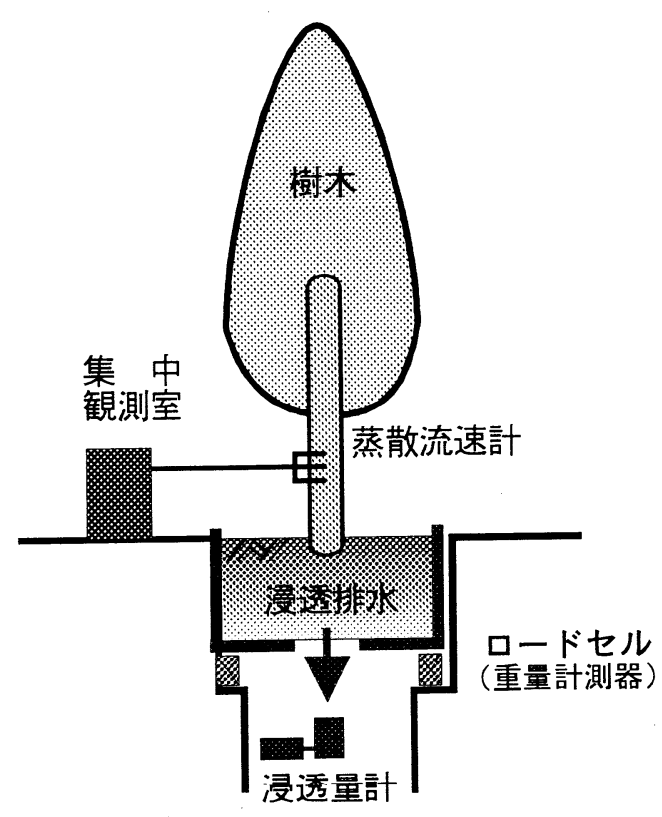

図-1 ライシメータの構造（側面図）

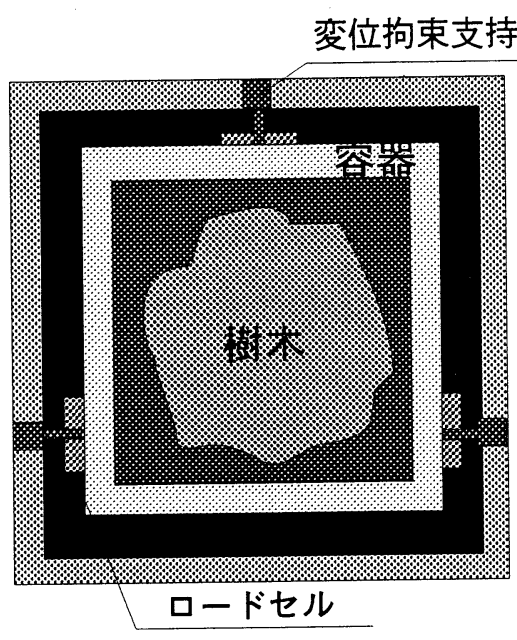

図-2 ライシメータAの平面構造

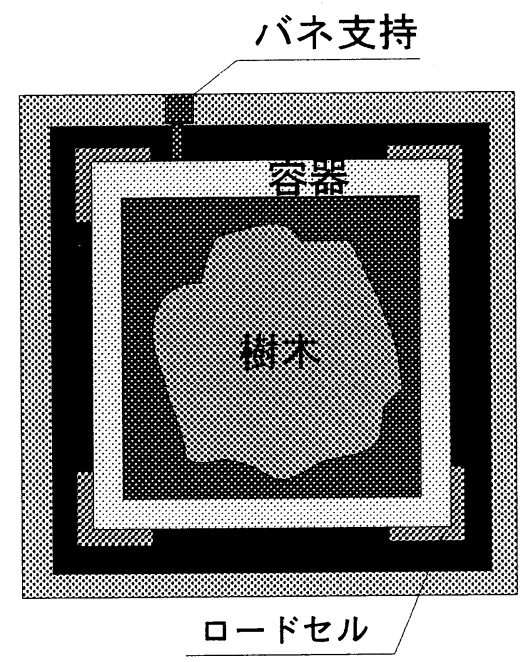

図-3 ライシメータBの平面構造 
のセンサ類を設置した。

気象デー夕 (気温, 相対湿度, 風速, 純放射量) はライシメータに隣接する高さ $12 \mathrm{~m} の$ 気象観測ポー ルに設置された気象測器（横河ウェザック社製, 温 度計：E-734-10, 湿度計：E-771-11, 風速計：A722, 示差放射計：H-221）により 5 分間隔で計測さ れ，G P I B インターフェースを介してメモリー カードへ一旦収録された後に，パーソナルコン ピュータへ転送して解析に供した。

なお，本年度は 2 日に一度 40 リットル程度の水を供 給し，サクション水頭にして $-100 \mathrm{~cm}$ 程度を維持する ようにしているため, 十分に土㙵水分がある条件下 での実験となっている。

\section{（2）デー夕の整理方法}

樹木が風を受けると重量デー夕が変動するため, 防風用の施設を設置することも考えたが，なるべく 自然な環境で実験が遂行されるように，ライシメ一 夕の周囲には防風施設を設けていない. したがって 重量の生データには主として風速の影響による短周 期のノイズが重畳されているため，2 時間の移動平 均を施して重量デー夕を平滑化した。1 時間毎に蒸 散量を計算するべく, i 時30分の重量值を $W(i)$, $i+1$ 時 30 分の重量值を $W(i+1)$ とすると, 基本 的にはこの 1 時間における重量変化量を $\mathrm{i}+1$ 時に おける蒸散量と定義できる。しかしながら，この デー夕には浸透排水による重量減少とライシメータ 自体の温度変化にともなう重量変化が見かけの蒸散 量として含まれているため, これらの影響を除去し ないと実蒸散量を評価することはできない。

浸透排水量については，同時間帯での積算浸透量 $I(i+1)$ を差し引くことで実蒸散量への補正が可 能である.

一方，ライシメータの温度変化特性については, 樹木を容器に移し替える前に 1 回と, 今夏の 1 回の 計 2 回について蒸散量の影響を受けない状態で，見 かけ上発生する重量変動とこれへの影響因子との関 係を定式化した ${ }^{3)}$. 今夏については, 樹木に厚さ $2 \mathrm{~mm}$ で三重構造の遮光シートを被せて, 蒸散が発生 しないように工夫した。 その結果, 容器底部の補剛 用 $\mathrm{H}$ 型鋼の上に設置したサーミス夕温度計の出力値 と相関が高く, 蒸散が始まる午前 6 時を起点として, 容器の温度偏差 $x$ と総重量の偏差 $y$ とが図 -4 と図 -5 に示すようにまとめられた。 これらを定式化すると 次式のようである.

$$
\begin{gathered}
\text { ライシメータ } \mathrm{A} \text { (ケヤキ) : } \\
y=0.349 x+0.270 \\
\text { ライシメータ B (スギ }): \\
y=0.781 x-0.203
\end{gathered}
$$

上式による補正量を $W T(i+1)$ とおけば, 最終 的に実蒸散量 $E T(i+1)$ は次式で計算される.

$$
E T(i+1)=W(i)-W(i+1)-I(i+1)-y
$$

枝葉の繁茂状況が異なるケヤキとスギとを同一の 基準で評価するためには, 前述の解析で得られた蒸 散量を, 実際に蒸散に寄与すると考えられる実葉面 積で除して, 樹木毎の蒸散強度を計算すれば都合が よい. 実葉面積の算定には, 樹木を下部と上部から 写真撮影した結果を利用する. 下部からの撮影で, 枝葉のない部分が明るく写るため, 枝葉のギャップ を求めることができる. したがって枝葉に占める面 積率は, 樹冠の投影面積内で葉の部分が実質的に占 めている面積率として算定しうる. また上部から撮 影する際に樹冠の最下端に1mの基準スケールを置い ているので，これを基に樹冠の支配面積が容易に算 定される. 以上により樹冠の外縁線内の樹冠投影面 積 $A$ とそれに生きた枝葉部分（枯れ枝を除いた）の



図-4 容器温度偏差之重量偏差の関係 (ライシメータA)

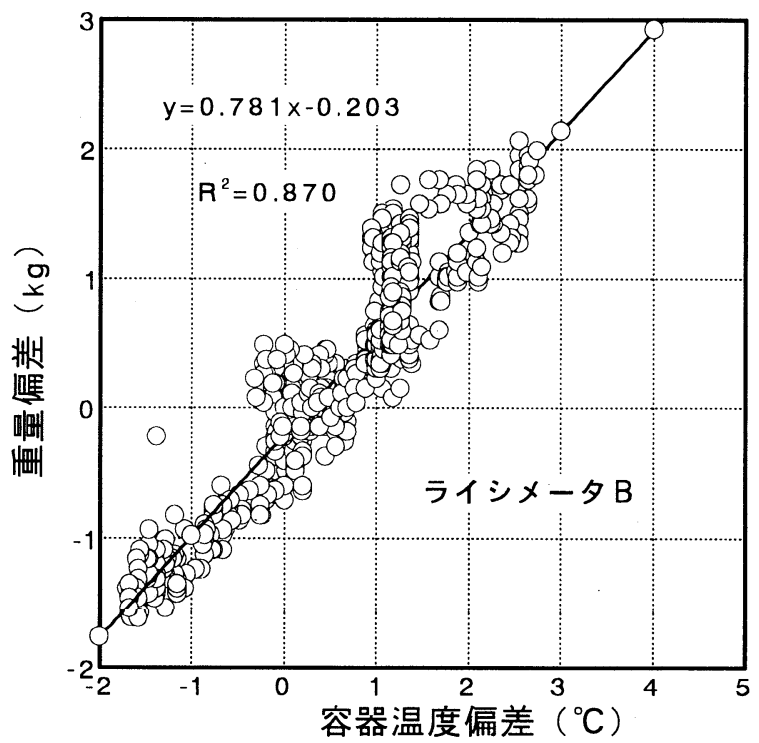

図-5＼cjkstart容器温度偏差と重量偏差の関係 (ライシメータB ) 

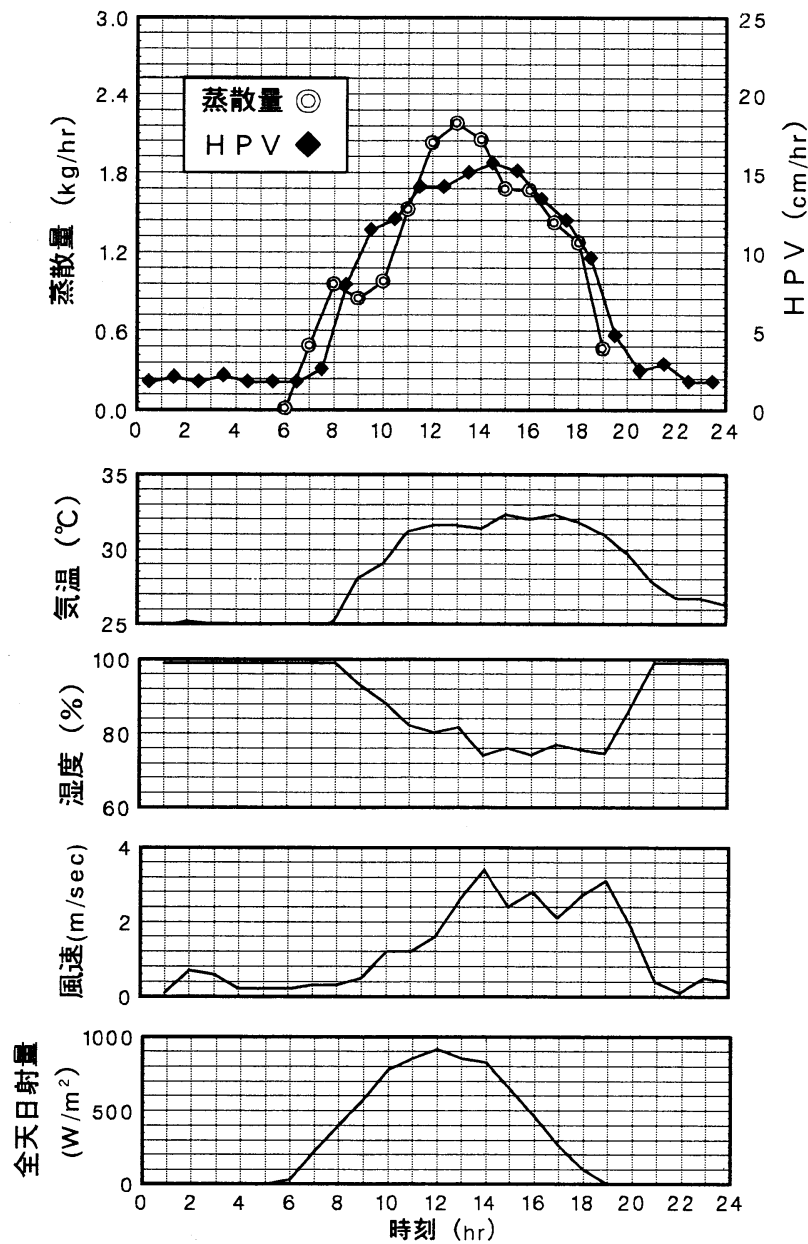

図-6 蒸散量, ヒートパルス速度, 気象量の経時変化例 （ケヤキ：1998年8月11日）

占める面積率 $P$ を求めた，なお，通常の樹木である と樹冠の階層性を考慮した葉面積指数（L A I ）を 求めることが多いが，今回の対象樹木では，主とし て外縁部に枝葉が分布していたので, 枝葉の重なり を考慮する必要がないと判断した。

その結果，ケヤキとスギでそれぞれ $P_{1}=72.1 \%$ お よび $P_{2}=55.6 \%$ となった. したがって，ケヤキとス ギの樹冠投影面積がそれぞれ $A_{1}=17671 \mathrm{~cm}^{2}$ および $A$ ${ }_{2}=17892 \mathrm{~cm}^{2}$ であったことから, 実葉面積はそれぞれ $P_{1} A_{1}=9948 \mathrm{~cm}^{2}$ および $P_{2} A_{2}=12741 \mathrm{~cm}^{2}$ とできる.

\section{3．樹種毎における蒸散特性の検討}

\section{（1）ケヤキとスギの蒸散量の経時変化特性}

1998年8月11日〜8月13日に実施した実験結果につ いて，1時間当たりで整理した蒸散量，ヒートパル 又速度, 気温, 湿度, 風速, 全天日射量の経時変化 例を, ケヤキとスギの場合について, 図-6と図-7に それぞれ 1 例ずつ示す. 風と周囲の熱環境に起因す る変動を除去しても, 結果として蒸散量の経時変化 には一部に凹凸が認められた。しかしながら，1日 全体を通して見れば，ケヤキとスギのどちらについ


図-7 蒸散量, ヒートパルス速度, 気象量の経時変化例 （スギ：1998年8月11日）

ついても，蒸散強度の指標となるヒートパルス速度 の経時変化亡概ね合致していると判断される.

これらは，気温，湿度，全天日射量の経時変化と も符合している．風速については蒸散量の凹凸と必 ずしも対応しているとは言い難い部分があり，定常 的な影響よりはむしろ突発的な風による影響が大き くなると考えられる。

後ほど更に検討を加えるが，図-6と図-7からでは， 明らかにスギよりもケヤキの蒸散量の方が大きいこ 亡が分かる。これ以外の 2 日でもほぼ同様である。 しかしながら，この結果が直ちに広葉樹は針葉樹よ り屯多いという根拠にはならない，樹木による実質 的な蒸散強度あるいは蒸散効率を評価するためには, 実験時における実葉面積を基準とした解析が必要で ある。

\section{（2）蒸散量とヒートパルス速度とのずれ時間}

既往の研究 ${ }^{3 ） 4 ~} 4$ より，樹木のサイズによらず, 蒸散量とヒートパルス速度とには「ずれ時間」が存 在することが報告されている，観測者によって時間 の長さに若干の差異は認められるが，例えば著者ら の観測結果からは，樹高が $2 \mathrm{~m}$ スギ，ヒノキ，サン ゴジュについて，蒸散量の経時変化に対してヒート 
パルス速度の経時変化は概ね 1 時間程度遅れること

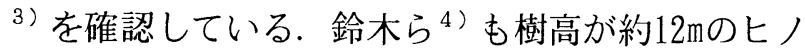
キについてずれ時間がおよそ 1 時間程度であること を報告している．今回の結果もこの観点から検討し てみると，このことは図-8と図-9に示すように，蒸 散量の経時変化が凹凸な関係で若干いびつであるが, 蒸散量とヒートパルス速度とを 2 次元プロットした 場合に，両者は閉じた 1 価の関係というよりは, ループが現れる 2 価の関係にある点から容易に確認 できる.

主として早朝の立ち上がり部分，および夕方の派 減部分のいずれをみても，日によって若干の前後は あるが，スギとケヤキで明確な差はなく，従来通り

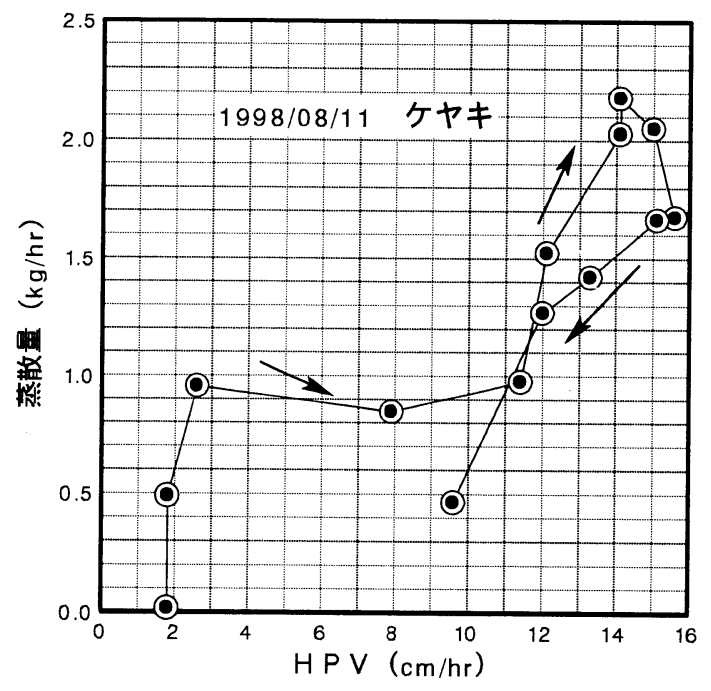

図-8 蒸散量とヒートパルス速度との相関関係 （ケヤキ：1998年8月11日）

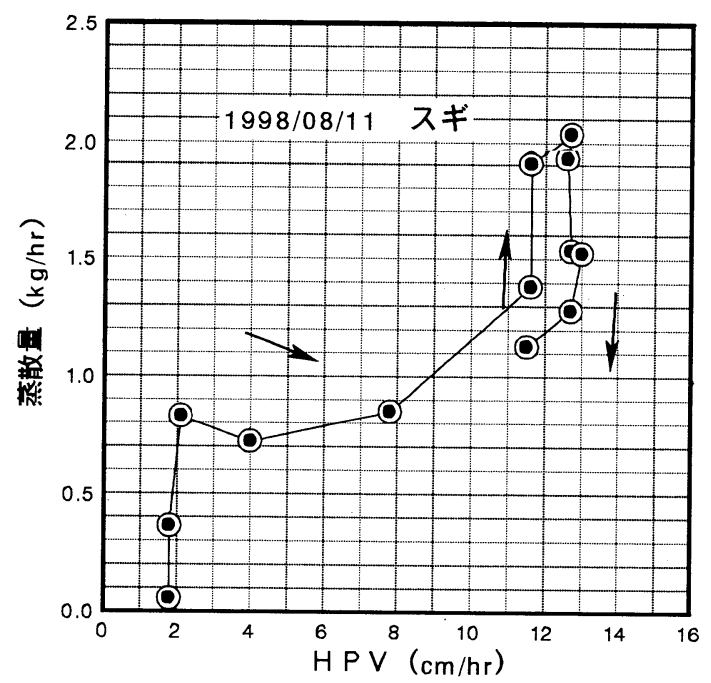

図-9 蒸散量とヒートパルス速度との相関関係 （スギ：1998年8月11日）
ずれ時間は30分から 1 時間程度と判断される. 特に, 樹高や樹齢が概ね同じ場合に，広葉樹と針葉樹とい う樹種の差異が樹木の蒸散特性に及ぼす影響につい て興味が持たれるが，今回の結果を見る限りでは， 両者に大差はなさそうであり，あっても誤差の範囲 程度であろう。

\section{4.広葉樹と針葉樹における蒸散強度の差異}

\section{（1）実質蒸散強度の評価法}

図-6から図-9を一見すると，広葉樹であるケヤキ の方が針葉樹であるスギよりも蒸散量は大きいとい う誤解を生む可能性がある. そこで, 既に求めてあ る枝葉の隙間部分を含まない樹木の実質葉面積を基 準面積として, 樹木として実質葉面積あたりの蒸散 強度の差異について検討する。ここでは葉面積のみ に着目し，樹高の大小のような個体差に依存する条 件については考慮の対象外として，得られた結果を 整理する. 具体的には，これまでに得られた蒸散量 を実験対象木としたケヤキとスギそれぞれの実質葉 面積 $P_{1} A_{1}$ およびによって除すことにより実蒸散強 度を定義する。

\section{（2）実蒸散強度による樹種間の比較検討}

前述のの定義に従って求めた実蒸散強度によるケ ヤキとスギの比較例を図-10から図-12に示す.

これらの図を見ると, 日によって両者の大小関係が 逆転する場合も見受けられるが，少なくともどちら かがもう一方に対して圧倒的に大きいという事実は 認められない。したがって, 実葉面積を算出する際 の䛊差をも考慮すれば，図示の範囲であれば，ケヤ キとスギとの間に顕著な蒸散強度の差異は認められ ないと考えるのが妥当であろう。

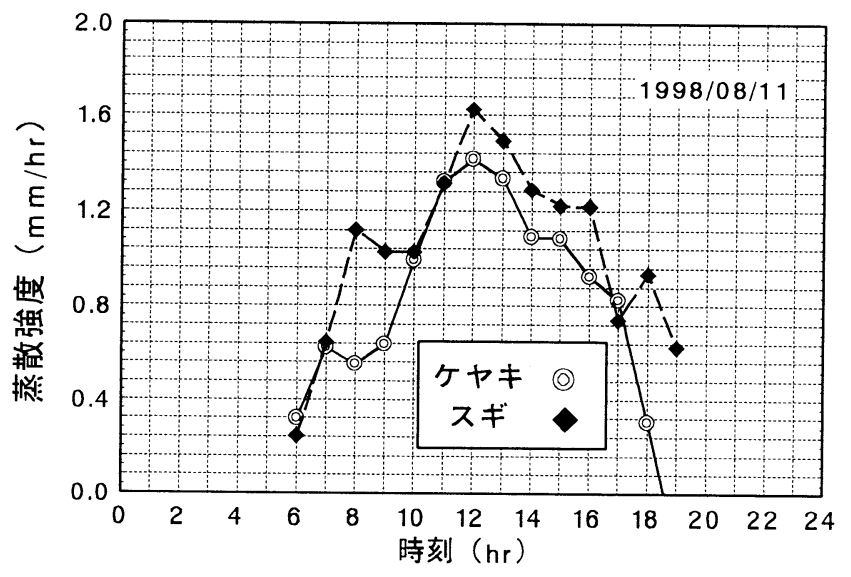

図-10 樹種による実質蒸散強度の比較例 （1998年8月11日） 


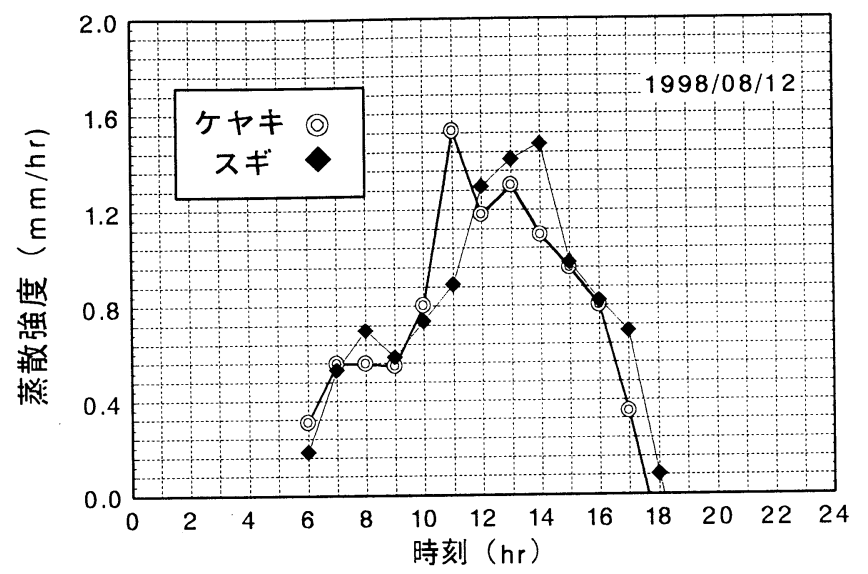

図-11 樹種による実質蒸散強度の比較例 (1998年8月12日)

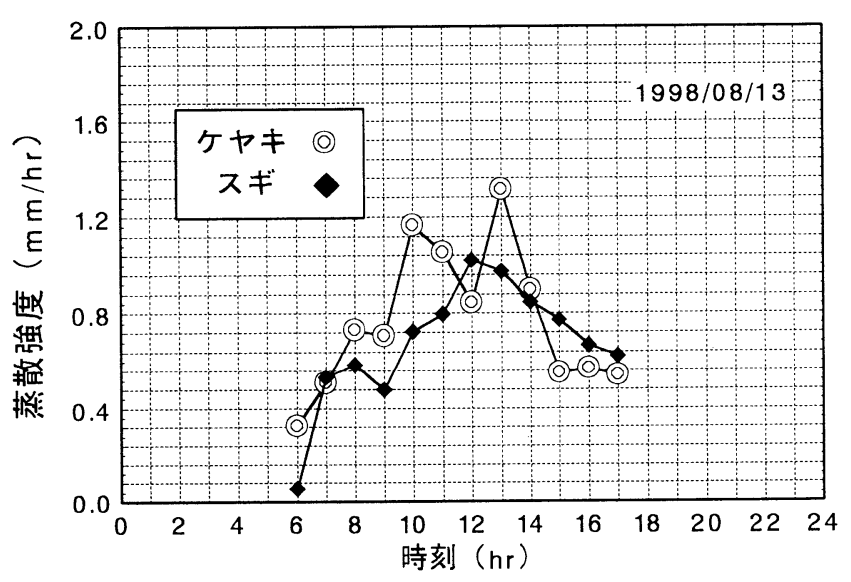

図-12 樹種による実質蒸散強度の比較例 （1998年8月13日）

表-1 日蒸散量の比較 (単位: $m$ m/day)

\begin{tabular}{|c||c|c|c|}
\hline 実験日 & $8 / 11$ & $8 / 12$ & $8 / 13$ \\
\hline ケヤキ & 1.109 & 0.998 & 0.887 \\
\hline スギ & 1.365 & 1.021 & 0.869 \\
\hline
\end{tabular}

一方で，蒸散量が現れている時間带（概ね午前6 時から午後 6 時まで）での蒸散量を積算した日蒸散 量をケヤキとスギで比較した例が表-1である. 日に よって多少の大小逆転はあるが, やはり日単位で見 ても, 蒸散強度の結果と同様に樹種間での顕著な差 異は認められない.したがって, この場合に単木と
しての蒸散量の大小を支配するのは, 土壤水分の久 乏にともなう吸水制限のような植物生理学的過程に 影響を及ぼす外因とそれに対する樹木の感度の差異 か，実質蒸散面積の差異，すなわ枝葉の繁茂度が考 えられる，林分以上のスケ一ルとなれば，樹木密度 が大きな影響因子となってくるだろう。

\section{4. おわりに}

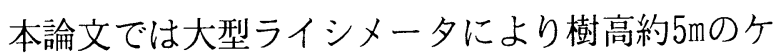
ヤキ(落葉広葉樹) とスギ（常緑針葉樹）の蒸散量 を計測し，それぞれにおける蒸散量と周囲環境亡の 関係や樹種間での差異を比較検討した. その結果, 今回の観測の範同においては，広葉樹と針葉樹とで 蒸散量や蒸散過程に明瞭な差異は認められなかった. 速断は禁物だが, 今後の解析における一つの見通し として，実質的な蒸散強度で見れば，樹種間で顕著 な差異は無い，亡いう一般に言われている知見とは 異なる可能性が示唆された。今後は同一の方法論で 蒸散効率を論じるために，著者らのヒートパルス蒸 散モデルを観測值へ適用し，同定されるモデルパラ メ一夕值の差異や, 蒸散係数の大小を通して更なる 検討を加えたいと考えている.

謝辞：徳島県農林水産部森林整備課ならびに徳島県 森林土木協会より，ライシメー夕および気象観測施 設の設置について格別のご協力をいただきました。

また, 徳島県林業総合技術センターには構内の一角 をライシメー夕建設用地として提供いただきました。 観測，解析に当たっては，昨年度の大学院生福本憲 弥氏, 4 年生の故坂本昌興氏のご協力を得ました. ここに記して謝意を表します。

\section{参考文献}

1) 古田弘, 端野道大, 村岡浩爾：ヒ一トパリス速度を利 用した蒸散量推定のために数理モデルの提案, 水文・ 水資源学会誌, Vol.6, No.3, pp.244-253, 1993.

2) Nakagawa, S. : Study on evaporation from pasture, Environmental Research Center Papers, The University of Tsukuba, pp. 18-26, 1980.

3) 福本憲弥: 大型ウェイングライシメータを利用した蒸散 量推定に関する基礎的研究, 徳島大学大学院工学研究 科修士論文, pp. 26-39, 1998.

4) 鈴木雅一：山地流域の蒸散量に関する森林水文学的研 究, 平成元年度文部省科学研究費補助金研究成果報告 書, pp. 1-59, 1990.

(1998. 9. 30受付) 